\title{
Clinical Review: Management of Adult Kasabach-Merritt Syndrome Associated with Hemangiomas
}

\author{
Master S, Kallam D, El-Osta $\mathbf{H}$ and Peddi P* \\ Department of Medicine, Division of Hematology \& Oncology, Louisiana State University Health Sciences Center, USA
}

*Corresponding author: Prakash Peddi, Assistant Professor of Medicine, Division of Hematology \& Oncology, Louisiana State University Health Sciences Center, USA Tel: 318-813-1057; E-mail: ppeddi@Isuhsc.edu

Received date: Nov 07, 2017; Accepted date: Dec 20, 2017; Published date: Dec 27, 2017

Copyright: (C) 2017 Master S, et al. This is an open-access article distributed under the terms of the Creative Commons Attribution License, which permits unrestricted use, distribution, and reproduction in any medium, provided the original author and source are credited.

\begin{abstract}
Kasabach-Merritt syndrome (KMS) consists of a clinical trial of capillary hemangioma, thrombocytopenia and disseminated intravascular coagulation. KMS occurs most commonly in the pediatric population, and its occurrence in adults is rare. Specific guidelines or randomized clinical trials guiding clinical management of KMS in adult patients are lacking. This manuscript provides a comprehensive review of KMS and discusses recent advances in the medical management of KMS. We also propose a systematic therapeutic approach which would serve as a guide in the management of adult patients with KMS caused by hemangiomas.
\end{abstract}

Keywords: Kasabach-Merritt syndrome; Kasabach-Merritt syndrome in adult; Kasabach-Merritt syndrome management; Disseminated intravascular coagulation in hemangioma; Hemangioma management; Kasabach-Merritt syndrome pathophysiology; Advances in Kasabach-Merritt syndrome management

Abbreviations: KMS: Kasabach-Merritt syndrome; KHE: Kaposiform hemangioendothelioma; DIC: Disseminated intravascular coagulation; MRI: Magnetic resonance imaging

\section{Introduction}

Kasabach-Merritt syndrome (KMS, also called as Kasabach-Merritt phenomenon (KMP) encompasses a triad of capillary hemangioma, thrombocytopenia, and consumptive coagulopathy [1]. KMS manifests as a secondary complication of a tufted angioma (TA), kaposiform hemangioendothelioma (KHE), hemangioma, angiosarcoma or even an aneurysm. Most of the available literature on KMS and its management stems from pediatric studies, with limited reporting on the management of KMS in the adult population. KMS is a rare presentation in adults, and its exact incidence is unknown. In terms of pediatric literature, TA and KHE are rare, with incidence of KHE estimated at $0.07 / 1000,000$ children per year $[2,3]$. The incidence of KMS in patients with KHE and TA are $70 \%$ and $10 \%$ respectively $[4,5]$. TA and KHE share several histopathologic similarities, while TA is a benign tumor characterized by tufts of capillaries within the dermis, $[3,4]$ KHE tends to be locally aggressive tumor that may involve superficial or deep soft tissues $[4,6]$. In the adult population, KMS is seen most often as a complication from hemangiomas [7], hemagiomatosis [4] or angiosarcoma [8].

Hemangiomas are benign mesenchymal tumors, usually involving the liver or spleen. They are well-circumscribed lesions surrounded by thin capsule and their size can range from few millimeters to few centimeters $(\mathrm{cm})$. Histologically, the tumor is composed of cavernous vascular spaces lined by a single layer of endothelium and these vascular compartments contain thin fibrous septae which may develop collagenous scar which in turn may initiate thrombosis. The term giant hemangioma usually refers to a hemangioma whose size is more than 5 $\mathrm{cm}$ [9]. It is not clear if there is any linear relation to the size of the hemangioma and the initiation of KMS, but most of the KMS cases are reported in giant hemangiomas. Whether a specific organ system (or site) which harbors the hemangioma confers increased predilection towards initiating KMS is also unclear.

In contrast to hemangiomas, angiosarcomas are uncommon malignant neoplasms characterized by rapidly proliferating, extensively infiltrating anaplastic cells derived from endothelium. These tumors tend to be more aggressive, recur locally, spread widely, and have a high rate of lymph node and systemic metastases. Common sites of angiosarcoma include liver, breast, spleen, bone and heart. Histologically, low-grade lesions have vascular spaces lined by large endothelial cells that penetrate the stroma and papillary fronds of cells that project into the lumen. Higher-grade lesions are more cellular, with atypical cells and abnormal mitoses. Immuno- histochemical studies show CD31 and Factor VIII positivity in these malignant cells.

\section{Clinical case}

A 35-year-old African American woman sustained a sub trochanteric fracture of the left femur after a minor fall from standing height. She had no significant past medical history apart from gradually progressing discomfort in her left upper thigh for duration of one year. Pertinent surgical and family history was negative. Initial magnetic resonance imaging (MRI) of the left thigh, with and without contrast, revealed a large $15 \times 9 \mathrm{~cm}$ peripherally enhancing soft tissue mass (Figures $1 \mathrm{~A}$ and $1 \mathrm{~B}$ ). The initial patient's hematological and coagulation parameters were within normal range. Surgical biopsy of the left femur mass was consistent with hemangioma with a secondary aneurysmal bone cyst (Figure 2A).

Immuno-histochemical studies revealed CD31 positive vascular lining (Figure 2B). Feeding artery (left deep femoral) embolization was performed, along with tumor debulking, open reduction and internal fixation with intramedullary nailing. A follow-up MRI performed 3 months later revealed a recurrent larger vascular lesion, which measured $16 \times 11 \mathrm{~cm}$ (Figure 1C). The patient again underwent partial 
embolization of the deep femoral artery, which was unsuccessful. Repeat MRI scan showed an enlarging mass (Figure 1D), measuring 17 $\times 12$ centimeters). The patient was referred to the hematology and oncology clinic for further management. Both swelling and pain over the left upper thigh continued to increase, with development of skin bruising, gingival bleeding and worsening hemorrhoid bleeding. A complete blood picture revealed hemoglobin at $12.1 \mathrm{~g} / \mathrm{dL}$, white blood cell count of $9 \times 10^{3} / \mu \mathrm{L}$ and platelet count of $10^{8} \times 10^{3} / \mu \mathrm{L}$. The platelet counts immediately trended to $36 \times 10^{3} / \mu \mathrm{L}$. The coagulation profile revealed D-dimer $>20 \mu \mathrm{g} / \mathrm{mL}$, fibrinogen $62 \mathrm{mg} / \mathrm{dL}$, prothrombin time (PT) 18.6 seconds, international normalized ratio (INR) 1.5 and partial thromboplastin time (PTT) 39.1 seconds, which was consistent with disseminated intravascular coagulation (DIC). MRI revealed further increase in the size of the hemangioma (Figure 1E).

In the context of thrombocytopenia, coagulopathy and left femur hemangioma, the patient was diagnosed with Kasabach-Merritt syndrome. On admission, she was started on prednisone $(1 \mathrm{mg} / \mathrm{kg})$, fresh frozen plasma (FFP) and cryoprecipitate with a goal to keep fibrinogen above $100 \mathrm{mg} / \mathrm{dL}$. Aminocaproic acid was added as an adjunct to control bleeding diathesis. Repeated attempts of embolization were unsuccessful, and surgical management was deferred secondary to coagulopathy.

Worsening coagulopathy (patient required 160 units of cryoprecipitate), despite all of the above treatments, led to initiation of intravenous vincristine $\left(1.4 \mathrm{mg} / \mathrm{m}^{2}\right.$ every 2 weeks, total of 4 doses) with concurrent radiation therapy (4,500 cGy in 25 fractions), along with continuation of daily oral prednisone $(1 \mathrm{mg} / \mathrm{kg})$. After completion of chemoradiotherapy, the prednisone was slowly tapered off over 2 months. At the end of this therapy, the lesion had regressed to $13 \times 10$ $\mathrm{cm}$ (Figure $1 \mathrm{~F}$ ) with complete normalization of the coagulation profile. Her disease has been in control for the past 44 months.

\section{Pathophysiology}

The pathogenesis of KMS is complicated and poorly understood. The proposed mechanism of KMS involves both primary and secondary hemostatic mechanisms, leading to platelet trapping, platelet activation/aggregation, and platelet consumption, along with activation of coagulation cascade within the abnormal vascular structure [10]. The site of platelet destruction has been a subject of controversy. Even though Indium-111 platelet scintigraphy studies demonstrate platelet trapping in the vascular lesion, the degree of thrombocytopenia is poorly correlative to the size of lesion.

In fact, other studies involving platelets labeled with Technetium-99m demonstrated lower level of platelet sequestration in vascular lesion compared to the spleen. The phenomenon of platelets destruction in spleen and not in vascular lesion could be explained by acquired platelet defects occurring in the vascular lesions, leading to their subsequent destruction in spleen [11]. It is also controversial as to why only a fraction of these vascular lesions lead to KMS. The most important structure which is at the epicenter of KMS initiation is endothelium. Kraling et al. [12] and Dosanjh et al. [13] demonstrated that hemangioma-derived endothelial cells showed increased expression of E-selection, a cell adhesion molecule and diffuse distribution of CD31 and von Willebrand factor (vWF), demonstrating an immature phenotype of the endothelium.

Endothelial damage also has been shown in bacterial $[9,14,15]$ and multiple viral infections (measles virus, rubella virus, herpes simplex virus, cytomegalovirus, human immunodeficiency virus, and other viruses) [16].

Regardless of the initiating factors, exposure of sub-endothelial collagen and tissue factor in rapidly changing endothelial cells leads to platelet binding via glycoprotein (GP)-Ib-V-IX and vWF, and subsequent activation of platelets. All these processes culminate in localized intravascular coagulopathy and can ultimately lead to lifethreatening disseminated intravascular coagulopathy [16].

Platelet trapping leading to thrombocytopenia, hypofibrinogenemia, and increased fibrinolysis can potentially cause intra-lesional bleeding and tumor enlargement [2,17,18]. Microangiopathic hemolytic anemia can be also seen in these patients. Vascular endothelial growth factor- alpha (VEGFA) also seems to play an important role in tumor enlargement. VEGFA is secreted by tumor cells, tumor stroma and by platelets [2].

\section{Clinical presentation}

Table 1 provides various presentations, treatments and outcomes of adult patients with KMS reported in the literature. As shown in the Table 1, KMS is more common in young adults and its incidence decreases steadily with age. The most common site involved includes liver and the extremities. Patients with KMS may present with rapidly enlarging painful mass, ecchymosis, overt bleeding symptoms or fractures.

High-output cardiac failure has been reported in the pediatric population, but this seems to be exceedingly rare in adults, with only two cases described in the literature [19]. The outcome in terms of morbidity and mortality is in a large part related to location, disease burden and severity of presentation. The degree of coagulopathy, accessibility of mass and side effects of treatment like drugs and surgical complications also affect the clinical outcomes.

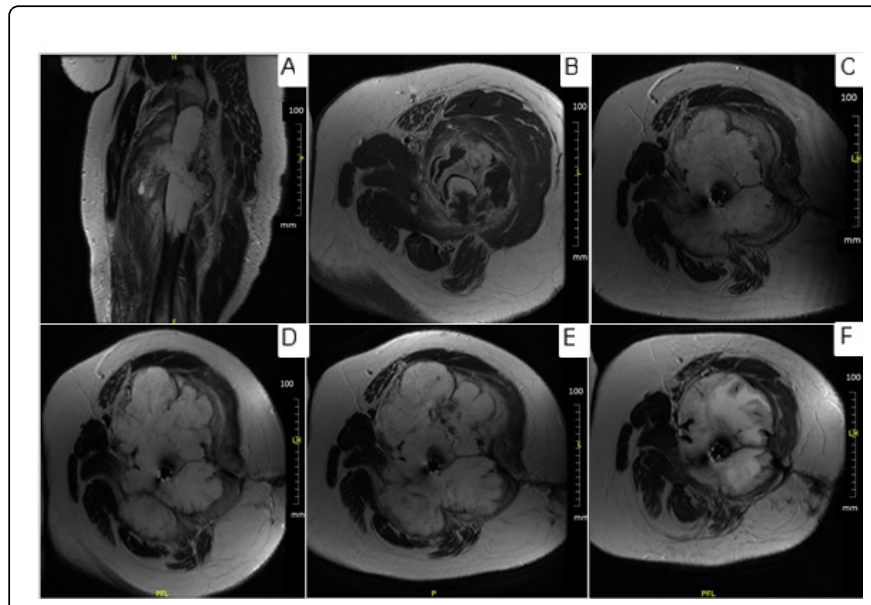

Figure 1: Magnetic Resonance Images of Left Thigh. 1A (sagittal) and $1 \mathrm{~B}$ (axial): $\mathrm{T} 1$ images with contrast at initial presentation demonstrating left femur fracture with surrounding hemangioma. 1C: T2 images at first recurrence following debulking and vascular embolization. 1D, 1E: T2 images of recurrent mass progressing after second vascular embolization. 1F: T2 images of the response after chemo-radiation. 


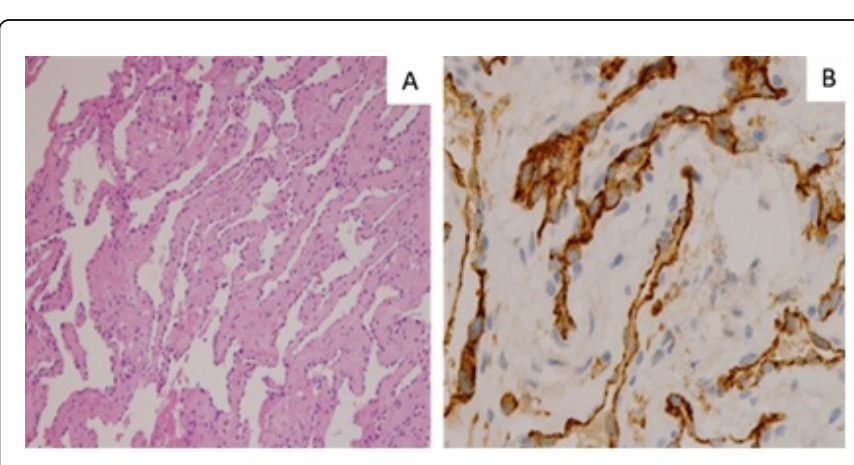

Figure 2: H\&E staining and CD31 Staining of Hemangioma. 2A: $\mathrm{H} \& \mathrm{E}$ staining demonstrating cavernous vascular spaces surrounded by single layer of flat endothelium filled with blood elements. 2B: Endothelial cells surrounding the vascular spaces with intense CD31 staining (dark brown).

\section{Diagnosis}

KMS is rare and high index of suspicion is required for timely diagnosis. In a patient with suspicion for KMS based on above clinical features, histopathologic diagnosis by biopsy is recommended. This is especially important if suspicion of angiosarcoma is high. Performing biopsy sometimes is complicated by the very vascular nature of the tumor itself and, coexisting coagulopathy, hence correction of coagulopathy is recommended prior to attempting any biopsy.

The imaging studies with magnetic resonance imaging (MRI) can delineate the extent of involvement and also help document the response to treatment. T1-weighted images with contrast show diffuse enhancement of mass and T2-images show a diffuse increased signal with stranding in the subcutaneous fat $[20,21]$. As shown in images (Figures 1A-1F), we used MRI for initial diagnosis and subsequent follow-up after various treatments. Doppler flow studies may help differentiate a solid mass from a vascular lesion.

Radionuclide imaging using Chromium-51 labeled platelets, Indium-111 labeled platelets (or) Iodine-131 labeled fibrinogen studies are probably more sensitive than computed tomography (CT) scans or MRIs for delineating the size and number of vascular lesions [22]. There have been reports of using radio nucleotide imaging to find hemangiomas in children. However, the use of radio nucleotide imaging is limited, as MRI and clinical findings are usually sufficient for diagnosis. There is no available literature to support the use of positron emission tomography (PET) scan in KMS.

\section{Management}

Because of the rarity of this manifestation and the absence of any randomized controlled trials, there are no clinical guidelines aiding in the management of KMS. The literature suggests use of multiple modalities for management of KMS.

Rather than concurrent treatment, more number of authors of published literature suggests use of sequential approach with various modalities for KMS $[23,24]$. The general approach is to manage coagulopathy effectively with supportive care and medical management [23-30] before proceeding with surgical or interventional treatments [31-35].

Management of KMS can be divided into the following overlapping categories:

1. Management of coagulopathy and aggressive supportive care

2. Systemic treatment

3. Corticosteroids

4. Systemic chemotherapy: vincristine, cyclophosphamide, actinomycin-D

5. mTOR inhibitors: Sirolimus

6. Antifibrinolytics: aminocaproic acid / tranexamic acid.

7. Antiplatelet therapy: aspirin, ticlopidine, dipyridamole and pentoxyphylline.

8. Anticoagulants: heparin / low molecular weight heparin.

9. Immunomodulators and anti-angiogenic agents: bevacizumab

10. Other agents: propranolol.

11. Surgical management

12. Embolization

13. Radiation therapy

14. Liver transplantation in liver hemangiomas or hemagiomatosis

15. Surveillance and follow up of treated patients.

\section{Management of coagulopathy}

The ultimate management of coagulopathy is treatment of vascular lesion, but the supportive care can be used as below.

\section{Platelets}

The authors recommend judicious use of platelet transfusion and restrict its use cases of active bleeding or prior to performing surgical procedures. Platelet counts in KMS can be alarmingly low, but lifethreatening hemorrhages are rarely seen [3]. The half-life of platelets is very short due to intra-lesion trapping and destruction, leading to its ineffectiveness. The platelets transfusion can be harmful in that it can accumulate in the lesions leading to increase in size [36]. The transfused platelets can release pro- angiogenic growth factors which can further worsen the symptoms [37].

\section{Reversal of coagulopathy}

Similar to platelets, use of cryoprecipitate and fresh frozen plasma for the correction of hypofibrinogenemia and coagulopathy should be given sparingly, and their use should be limited to: active bleeding, before surgical procedures, platelet count $<10,000 / \mu \mathrm{L}$ or fibrinogen $<1$ $\mathrm{g} / \mathrm{dL}[3,38]$. Recombinant factor VIIa can be used in active and uncontrolled bleeding [39]. The use of antifibrinolytics, like aminocaproic acid [40] and tranexamic acid [19,41-44] is limited to uncontrolled bleeding with low fibrinogen, elevated fibrin degradation products, and D-dimers. Transfusion of packed red blood cells should be considered when patient is symptomatic from anemia.

\section{Systemic therapy}

Pharmacologic systemic therapy is a significant part of multimodality treatment for KMS. When used as monotherapy only, the duration of response might be short lived [3,23, 24,45-47]. 
Citation: Master S, Kallam D, El-Osta H, Peddi P (2017) Clinical Review: Management of Adult Kasabach-Merritt Syndrome Associated with Hemangiomas . J Blood Disord Transfus 8: 397. doi:10.4172/2155-9864.1000397

Page 4 of 10

\begin{tabular}{|c|c|c|c|c|c|c|}
\hline Study & $\begin{array}{l}\text { Agel } \\
\text { Sex }\end{array}$ & Presentation & $\begin{array}{l}\text { Location of } \\
\text { Lesion }\end{array}$ & Tumor type & Treatment & $\begin{array}{l}\text { Outcomel Follow } \\
\text { up months }\end{array}$ \\
\hline Rodriguez et al. [2] & $70 / F$ & Abd. Pain & Liver & Angiosarcoma & Surgical Resection & Resolved / 8 \\
\hline Moussa et al. [9] & $55 / F$ & Breast Enlargement & Breast & Angiosarcoma & Steroids & Death / NA \\
\hline Salameh et al. [19] & $69 / M$ & Skin Lesion Bleed & $\begin{array}{l}\text { Scalp,Lung,GI } \\
\text { tract }\end{array}$ & Angiosarcoma & ACA,Steroids, Adriamycin,Vinc. & Death / NA \\
\hline Watzke et al. [40] & $35 / \mathrm{F}$ & Abd Pain + DIC. & Liver & Hemangioma & Heparin,FFP,Surgery & Resolved / 6 \\
\hline Wang et al. [43] & $26 / F$ & Uterine Bleeding & Spleen & Hemangiomas & $\begin{array}{l}\text { Tranexamic } \\
\text { acid,FFP,Splenectomy }\end{array}$ & Resolved / NA \\
\hline Giráldez et al. [51] & $37 / \mathrm{M}$ & Lower GI bleed & Meso-colon & Hemangioma & $\begin{array}{l}\text { Vinc.,Cyclophosphamide,Steroid } \\
\text { s }\end{array}$ & NA \\
\hline Chen et al. [52] & $20 / F$ & Femur Fracture, DIC & $\begin{array}{l}\text { Liver,Spleen,LE, } \\
\text { Vulva }\end{array}$ & Hemangioma & Cryo,FFP,Steroids, XRT,TAE & Resolved / $<1$ \\
\hline Fernandez et al. [60] & $52 / \mathrm{M}$ & Mass Head and Neck & $\begin{array}{l}\text { Face,Neck,Ches } \\
\mathrm{t}\end{array}$ & TA within a PWS & $\begin{array}{l}\text { Steroids,Vinc.,Cyclophosphamid } \\
\text { e,Imatinib,XRT,Bevacizumab }\end{array}$ & Improved / 26 \\
\hline Dufau et al. [98] & $72 / \mathrm{M}$ & Pleural Effusion & Spleen & Hemangiomatosis & Splenectomy & Death/ 2 \\
\hline Mahmoud et al. [99] & $39 / M$ & Lower GI Bleed & $\begin{array}{l}\text { Rectum,Liver,Sp } \\
\text { leen }\end{array}$ & Hemangioma & Surgical Resection & Resolved / 48 \\
\hline Tani et al. [100] & $67 / \mathrm{F}$ & Abd. Swelling & Liver & Hemangioma & Surgical Resection & Resolved / 2 \\
\hline Malagari et al. [102] & $52 / \mathrm{F}$ & Abd. Swelling & Liver & Hemangioma & TAE with Gelatin & Resolved/ 24 \\
\hline Malagari et al. [102] & $74 / \mathrm{F}$ & Melena + DIC & Liver & Hemangioma & TAE with Gelatin and Coils & Resolved / 24 \\
\hline Hochwald et al. [112] & $51 / \mathrm{F}$ & Abd. Swelling + DIC & Liver & Hemangioma & $\mathrm{XRT}$,Enucleation & Resolved/NA \\
\hline Biswal et al. [113] & $24 / M$ & LE Weakness & $\begin{array}{l}\text { Thoracic } \\
\text { Vertebra }\end{array}$ & Hemangiomas & $\mathrm{XRT}$ (30 Gy in 15 fractions) & Resolved/NA \\
\hline Habringer et al. [123] & $87 / M$ & Thrombocytopenia & Liver & Angiosarcoma & None (Advanced age) & Death / NA \\
\hline Imafuku et al. [124] & $67 / M$ & Scalp Ulcer & Scalp & Angiosarcoma & XRT,Heparin & Resolved /1 \\
\hline Bernathova et al. [125] & $28 / F$ & Breast Enlargement & Breast & Angiosarcoma & Chemotherapy,Surgery & NA \\
\hline Phillippe et al. [126] & $30 / F$ & $\mathrm{PPH}$ & $\begin{array}{l}\text { Face,Neck,Ches } \\
\text { t,LE }\end{array}$ & Hemangioma & Cryo,FFP,ACA,Heparin & Resolved / 2 \\
\hline Ontachi et al. [127] & $39 / F$ & Abd. Swelling & Liver & Hemangioma & $\begin{array}{l}\text { Danaparoid,Tranexamic } \\
\text { Acid,XRT }\end{array}$ & Resolved/NA \\
\hline Mewes et al. [128] & $62 / F$ & Abd. Swelling & Liver & Hemangioma & Heparin and Surgical resection & NA \\
\hline Longeville et al. [129] & $47 / M$ & Abd swelling + DIC & Liver & Hemangioma & Liver Transplant & Resolved / 12 \\
\hline Kumashiro et al. [130] & $48 / F$ & Abd. Swelling & Liver & Hemangioma & Liver Transplant & Resolved /NA \\
\hline Warrell et al. [131] & $45 / F$ & Chest Mass + DIC & Bone,Soft tissue & Hemangioma & ACA,Cryo & Resolved \\
\hline Menendez et al. [132] & $46 / \mathrm{F}$ & Femur Fracture & Bone,LE & Hemangioma & Platelets,Cryo & Resolved \\
\hline Shoji et al. [133] & $62 / \mathrm{F}$ & Hematuria + DIC & UE,LE & Hemangioma & Heparin,Steroids & Resolved / NA \\
\hline Singh et al. [134] & 20/F & $\mathrm{CHF}$ and $\mathrm{PPH}$ & $\begin{array}{l}\text { Face,Abd. } \\
\text { Wall,LE }\end{array}$ & Hemangiomas & Blood Products & Resolved / NA \\
\hline Singh et al. [134] & $21 / \mathrm{F}$ & $\mathrm{CHF}$ and $\mathrm{PPH}$ & $\begin{array}{l}\text { Face,Abd. } \\
\text { Wall,LE }\end{array}$ & Hemangiomas & Blood Products & Resolved/NA \\
\hline Klompmaker et al. [135] & $27 / M$ & Abd. Swelling + DIC & Liver & Hemangiomas & Resection and Liver Transplant & Resolved / 36 \\
\hline Courcoutsakis et al. [136] & $41 / \mathrm{F}$ & Breast Mass & Breast & Hemangiomas & NA & NA \\
\hline
\end{tabular}


Citation: Master S, Kallam D, El-Osta H, Peddi P (2017) Clinical Review: Management of Adult Kasabach-Merritt Syndrome Associated with Hemangiomas . J Blood Disord Transfus 8: 397. doi:10.4172/2155-9864.1000397

Page 5 of 10

\begin{tabular}{|l|l|l|l|l|l|}
\hline Lee et al. [137] & $69 / F$ & Mass Head and Neck & Face & Merkel cell cancer & TAE \\
\hline $\begin{array}{l}\text { Abd: Abdominal, ACA: Aminocaproic acid, CHF: Congestive Heart Failure, Cryo: Cryoprecipitate, DIC: Disseminated intravascular coagulation, Ext: Extremities, F: } \\
\text { Female, FFP: Fresh Frozen Plasma, GI: Gastrointestinal tract, LE: lower extremities, M: Male, NA: Not available, PPH: Post-partum hemorrhage, PWS: port-wine } \\
\text { stains, TAE: Transarterial Embolization, UE: Upper extremities, Vinc: Vincristine, XRT: Radiotherapy }\end{array}$ \\
\hline
\end{tabular}

Table 1: Overview of different presentations, treatments and outcomes of adult patients with KMS.

\section{Corticosteroids}

Greenberger et al. [65] in their studies on infantile hemangioma derived stem cells demonstrated that corticosteroids lead to suppression of vascular endothelial growth factor, monocyte chemoattractant protein-1, urokinase plasminogen activator receptor, and interleukin-6. All these factors are known targets of nuclear factor $\kappa$-light-chain-enhancer of activated B cells (NF- $\mathrm{B}$ ) [3]. Clinical effectiveness of corticosteroids in management of KMS has been validated in multiple clinical trials $[3,9,19,48-51]$. The initial dosing and the type of corticosteroids used in KMS vary based on the case series or case reports published. In general the choices can be: intravenous prednisololone $(2 \mathrm{mg} / \mathrm{kg} /$ day $)$ or methylprednisolone $(1.6$ $\mathrm{mg} / \mathrm{kg} /$ day $)$ or bolus doses of methylprednisolone $(30 \mathrm{mg} / \mathrm{kg}$ per day for three days) [3,23,52-57]. Due to long-term side effects of steroids, weaning should be attempted over 4-8 weeks.

\section{Vincristine}

Vincristine, a microtubule inhibitor is the most studied systemic agent used in second line for KMS. Being a vesicant, it is recommended to be given intravenously via central venous line at 1-2 $\mathrm{mg} / \mathrm{m}^{2}$ per week $[19,29,30,53,58-60]$. In one case series, the average time for platelet recovery was two months, and the average time for hemangioma regression was four months [31]. The duration of the intended therapy is 20-24 weeks. Vincristine can be combined with other chemotherapy or antiplatelet drugs. Some studies have combined it with Adriamycin [33] or cyclophosphamide [61,62]. In a case series involving 11 patients, vincristine in combination with aspirin and ticlopidine $[19,51,60]$ demonstrated excellent clinical response, and this response was quicker than vincristine alone [63]. The response rate of vincristine when used with steroids approaches 78\% [30]. In 2013, an expert panel recommended steroids and vincristine as first-line treatment for KMS [64].

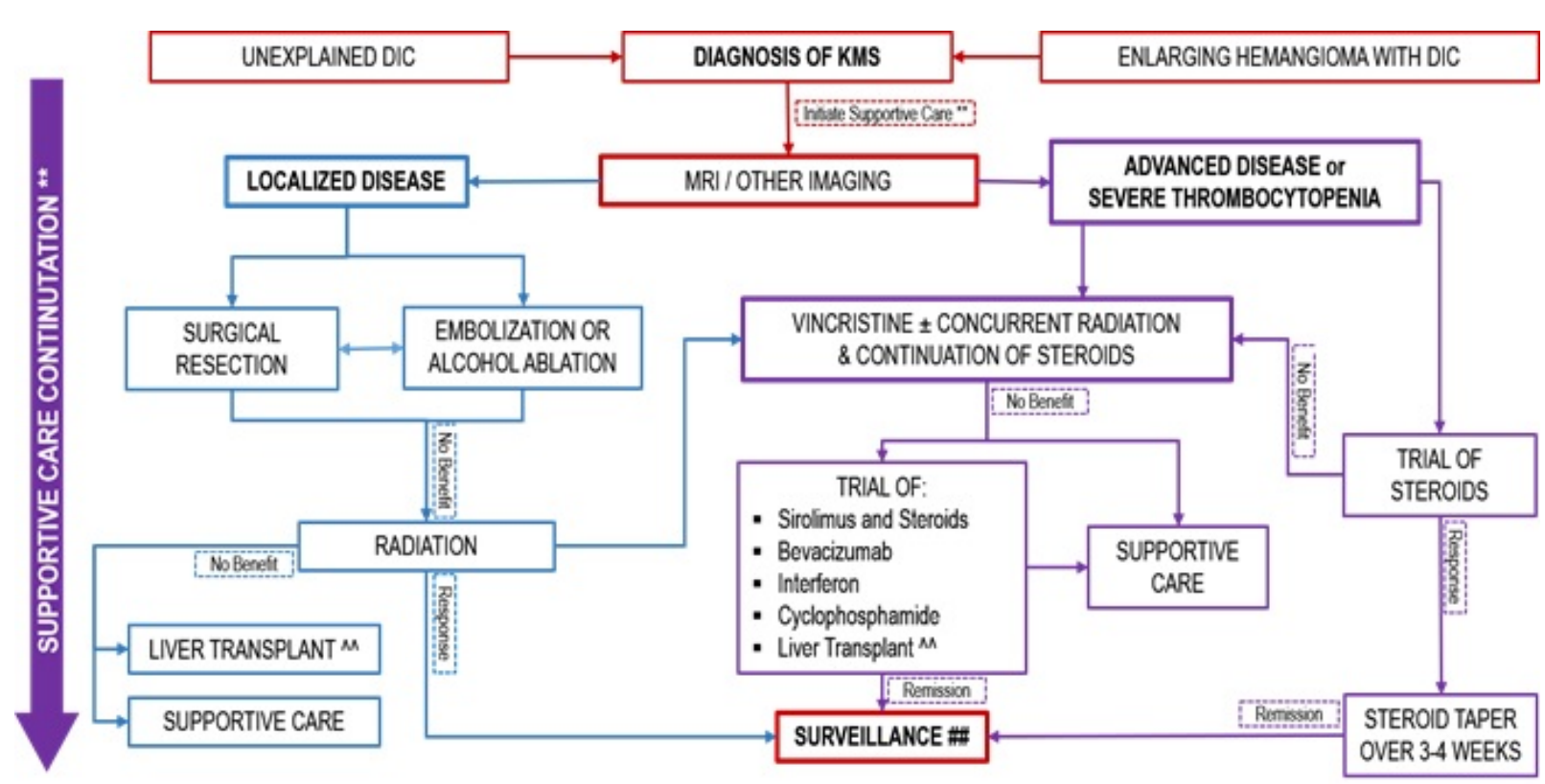

Figure 3: Treatment Algorithm of Adult Kasabach-Merritt Syndrome

\section{Other systemic chemotherapy agents}

Although there is not much experience in adult patients, both cyclophosphamide [64] and actinomycin D [65] have shown some activity in the management of hemangiomatosis and KHE causing KMS in the pediatric population. Liposomal doxorubicin and paclitaxel has been used in adults with angiosarcoma [66].

\section{Role of mTOR Inhibitors}

Mammalian target of rapamycin (mTOR) is a member of the serine/ threonine kinase protein family which is involved in various cellular processes like cell metabolism, angiogenesis and growth. mTOR is regulated by phosphoinositide-3-kinase (PI3K) [67]. The mTOR inhibitor sirolimus has been shown to inhibit lymphangiogenesis, and it has been successfully used as a treatment option for vascular anomalies in children [28,68-70]. Advantages of sirolimus include oral administration without the need for a central line and more rapid 
resolution of coagulopathy compared with a combination of vincristine and steroids. Some recent case reports have shown a rapid response of KHE and KMP to sirolimus [71-73]. In a case series reported by Kai et al., sirolimus was shown to be effective in children with refractory KHE with KMS. The response rates were $100 \%$, with significant improvement in signs and symptoms. The average time of response was only 5.3 days (ranging from 4 to 7 days), and the average platelet stabilization time was only 15.1 days (ranging from 5 to 28 days), which indicated the rapid efficacy of sirolimus in the treatment. The average time for sirolimus treatment in patients with KHE is 20.5 months (range, 13 to 26 months). Another study showed that Sirolimus is a well-tolerated. The common grade three side effects bone marrow toxicity in $27 \%$, gastrointestinal toxicity in $3 \%$ and metabolic toxicity in $3 \%[74,75]$.

\section{Antiplatelet therapy}

As previously mentioned, platelet activation and release of proangiogenic mediators is a major driver of the pathogenic process in KMS and this forms rationale for using antiplatelet agents. The antiplatelet agents that have been used in KMS include: Aspirin, Ticlopidine, Dipyridamole and Pentoxyphylline. Review of available literature does not support an increased risk of bleeding with use of antiplatelet agents in KMS, especially when there is no active bleeding. Although the data is controversial, the combination of aspirin and Ticlopidine appears to be the safest and most effective option [76-80]. Enjolras et al. reported that this combination was effective in $32 \%$ of patients in one series and $29 \%$ in another series $[63,81,82]$.

\section{Immunomodulators}

Use of interferon-alpha is reported in pediatric literature but there is a lack of any data in adults. Although some success with interferonalpha has been reported, the failure rates are also high $[81,83,84]$.

\section{Anti-Angiogenic Agents}

As mentioned earlier, VEGF-A is involved in pathogenesis of KMS and Bevacizumab is a recombinant humanized monoclonal antibody against VEGF-A. Bevacizumab's use is currently being explored in a variety of vascular malformations and vascular tumors [85-87]. Bevacizumab has been successfully used in combination with steroids and radiation $[88,89]$.

\section{Propranolol}

Published literature shows variable efficacy of use of propranolol in KMS. In a small case series of 11 patients, improvement was noted in only four cases [90]. Potential explanations of the therapeutic effect included vasoconstriction, decreased expression of VEGF and the triggering of apoptosis of capillary endothelial cells. Despite initial success in KMS [60], a larger series of patients reported poor results with only one-third of patients responding [91,92].

\section{Surgical Management}

Surgery is a feasible option for small, localized and accessible tumors or tumors whose size has been reduced by previous pharmacologic therapy. In patients who have failed medical treatment and, in life-threatening tumors surgery may serve as an important salvage option [92-94]. Wide local excision when possible and feasible is recommended [95]. Resolution of KMS has been reported in cases when complete resection is achieved [40,66,96-99].

\section{Others}

\section{Embolization}

In patients who are at high risk of bleeding, in addition to supportive care and medical management, trans arterial embolization (TAE) can provide a minimally invasive and non-radical treatment option [100]. In large tumors, TAE can be a useful bridge before surgery is attempted or until the systemic treatment becomes effective $[43,101,102]$. There are also multiple case reports of successful treated KMS with endovascular approaches [103-106]. As mentioned in Table 1 , KMS secondary to liver hemangiomas [107] and Merkel cell cancer involving the face [108] has been successfully treated with TAE. Intralesional injection of absolute alcohol [97] and steroids [102] have also been reported as management strategies.

\section{Radiation}

Procedural therapies other than surgical resection and TAE have included radiotherapy [52,109-112]. Historically, radiation therapy has been associated with multiple long-term side effects when used in pediatric population $[60,100,113-116]$ its use in adults has been more liberal. In a series of 28 patients, concurrent radiation and steroids demonstrated a $75 \%$ response rate, with no radiation-induced side effects over a median follow-up of more than 6 years [117]. With new advancements in radiotherapy, there is minimal radiation delivered to uninvolved organs and this can lead to more liberal use for adult population.

\section{Pneumatic compression}

Pediatric literature suggests a role for intermittent pneumatic compression in the management of vascular lesion [34]. It can be considered when the vascular lesion is located on an extremity. In some selected cases, it could be considered as an intermediate step before other treatments are pursued.

\section{Liver transplantation}

Hemangiomas involving the liver can be treated with enucleation. The procedure is generally curative $[23,118,119]$. Successful cases of liver transplantation have been performed in patients with hemangioma of the liver [120-122].

\section{Surveillance and follow up}

After the therapy is completed, remission pattern needs to be confirmed by close serial monitoring of platelets, hemoglobin, PTT, PT, INR and fibrinogen. Although how often and how long should labs be checked is arbitrary, authors recommend clinical evaluation along with lab monitoring every week for 4 weeks followed by monthly for 3-4 months and then serially every 3 months or as clinically required. Radiological assessments can be performed based on clinical indication. Worsening localized pain symptoms, new onset of thrombocytopenia or new onset coagulopathy should alert the physician to suspect relapse and treat accordingly.

\section{Our approach}

Once the diagnosis of KMS is established, authors recommend close monitoring of complete blood profile and coagulation parameters. Judicious and appropriate use of blood products like cryoprecipitate, fresh frozen plasma, platelets and packed red cells is advised. The need 
for adequate control of pain symptoms in symptomatic patients cannot be understated. MRI is recommended to accurately estimate the size and extent of the lesions. In absence of specific clinical guidelines and randomized trials, choice of therapy should be individualized after discussion with the patient and the family. Surgery is considered in patients with small and resettable lesions. In patients where initial surgery is not an option, we recommend high dose corticosteroids as an initial therapy, and if response is not achieved within a week, we recommend adding vincristine. Vincristine along with steroids alone or, with concurrent radiation should be considered. Vincristine is typically administered for 20 to 24 weeks, based upon the tumor response to treatment and acceptable therapy-related toxicity. In a very symptomatic patient or in cases associated with severe thrombocytopenia combined vincristine and radiation therapy along with supportive care may be an effective initial approach. Tumor embolization should be considered as a parallel strategy throughout this process. In a refractory setting, sirolimus with steroids, cyclophosphamide, interferon, bevacizumab, antiplatelet agents, propranolol, and mTOR inhibitors can be attempted. Once a remission pattern is obtained on steroids, we recommend a slow taper of corticosteroids over 3-4 weeks, before surveillance and follow up is started.

\section{Source of funding}

None

\section{Conflict of Interest}

All authors confirm no conflict of interest.

\section{Acknowledgements}

The authors wish to acknowledge the authors of previous studies and case reports on KMS as mentioned in references.

\section{References}

1. Kasabach HH, Katharine MK (1940) Capillary hemangioma with extensive purpura: report of a case. Am J Dis Child 59: 1063-1070.

2. Rodriguez V (2009) Kasabach-merritt phenomenon: case series and retrospective review of the mayo clinic experience. J Pediatr Hematol Oncol 31: 522-526.

3. Ryan C (2010) Kasabach-Merritt phenomenon: A single centre experience. Eur J Haematol 84: 97-104.

4. Croteau SE (2013) Kaposiform hemangioendothelioma: Atypical features and risks of Kasabach-Merritt phenomenon in 107 referrals. J Pediatr 162: 142-147.

5. Kelly M (2010) Kasabach-Merritt phenomenon. Pediatr Clin North Am 57: 1085-1089.

6. Cho KH (1991) Angioblastoma (Nakagawa)--is it the same as tufted angioma? Clin Exp Dermatol 16: 110-113.

7. Jones EW, Orkin M (1989) Tufted angioma (angioblastoma). A benign progressive angioma, not to be confused with Kaposi's sarcoma or lowgrade angiosarcoma. J Am Acad Dermatol 20: 214-225.

8. Zukerberg LR, Nickoloff BJ, Weiss SW (1993) Kaposiform hemangioendothelioma of infancy and childhood. An aggressive neoplasm associated with Kasabach-Merritt syndrome and lymphangiomatosis. Am J Surg Pathol 17: 321-328.

9. Moussa SH (2002) Angiosarcoma of the breast associated with KasabachMerritt syndrome. Arch Gynecol Obstet 267: 43-45.
10. KARSLIOĞLU Y (2008) A splenic hemangiomatosis case manifested by Kasabach-Merritt syndrome in an adult. Turkish Journal of Pathology 24: 107-110.

11. Wen S (2016) Angiosarcoma of the scalp and face associated with Kasabach-Merritt syndrome and disseminated intravascular coagulation. Indian J Dermatol Venereol Leprol 82: 96-97.

12. Baer HU (1992) Enucleation of giant hemangiomas of the liver. Technical and pathologic aspects of a neglected procedure. Ann Surg 216: 673-676.

13. Lyons LL (2004) Kaposiform hemangioendothelioma: a study of 33 cases emphasizing its pathologic, immunophenotypic, and biologic uniqueness from juvenile hemangioma. Am J Surg Pathol 28: 559-568.

14. Kräling BM (1996) E-selectin is present in proliferating endothelial cells in human hemangiomas. Am J Pathol 148: 1181-191.

15. Dosanjh A (2000) In vitro characteristics of neonatal hemangioma endothelial cells: similarities and differences between normal neonatal and fetal endothelial cells. J Cutan Pathol 27: 441-450.

16. Mantovani A, Dejana E (1989) Cytokines as communication signals between leukocytes and endothelial cells. Immunol Today 10: 370-375.

17. Benditt EP, Barrett T, McDougall JK (1983) Viruses in the etiology of atherosclerosis. Proc Natl Acad Sci U S A 80: 6386-6389.

18. Arcomano MA (1991) Metastatic angiosarcoma with thrombocytopenia and intratumoral indium-111-platelet deposition. J Nucl Med 32: 2278-2280.

19. Salameh F (2007) Metastatic angiosarcoma of the scalp causing Kasabach-Merritt syndrome. Am J Med Sci 333: 293-295.

20. Arunachalam P, Kumar VR, Swathi D (2012) Kasabach-Merritt syndrome with large cutaneous vascular tumors. J Indian Assoc Pediatr Surg 17: 33-36.

21. Banks RE (1998) Release of the angiogenic cytokine vascular endothelial growth factor (VEGF) from platelets: significance for VEGF measurements and cancer biology. Br J Cancer 77: 956-964.

22. Enjolras O (1990) Management of alarming hemangiomas in infancy: a review of 25 cases. Pediatrics 85: 491-498.

23. Shin HY, Ryu KH, Ahn HS (2000) Stepwise multimodal approach in the treatment of Kasabach-Merritt syndrome. Pediatr Int 42: 620-624.

24. Wananukul S, Nuchprayoon I, Seksarn P (2003) Treatment of KasabachMerritt syndrome: a stepwise regimen of prednisolone, dipyridamole, and interferon. Int J Dermatol 42: 741-748.

25. Pampin C (2000) Intratumoral consumption of indium-111-labeled platelets in a child with splenic hemangioma and thrombocytopenia. J Pediatr Hematol Oncol 22: 256-258.

26. Sadan N, Wolach B (1996) Treatment of hemangiomas of infants with high doses of prednisone. J Pediatr 128: 141-146.

27. Nako Y (1997) Successful interferon therapy in a neonate with lifethreatening Kasabach-Merritt syndrome. J Perinatol 17: 244-247.

28. Hu B (1998) Kasabach-Merritt syndrome-associated kaposiform hemangioendothelioma successfully treated with cyclophosphamide, vincristine, and actinomycin D. J Pediatr Hematol Oncol 20: 567-569.

29. Drucker AM (2009) Vincristine and corticosteroids as first-line treatment of Kasabach-Merritt syndrome in kaposiform hemangioendothelioma. J Cutan Med Surg 13: 155-159.

30. Lopez V (2009) Successful management of Kaposiform hemangioendothelioma with Kasabach-Merritt phenomenon using vincristine and ticlopidine. Pediatr Dermatol 26: 365-366.

31. Hara K (2009) Successful treatment of Kasabach-Merritt syndrome with vincristine and diagnosis of the hemangioma using three-dimensional imaging. Pediatr Hematol Oncol 26: 375-380.

32. Hartman KR (2009) Mediastinal Kaposiform hemangioendothelioma and Kasabach-Merritt phenomenon in an infant: treatment with interferon. J Pediatr Hematol Oncol 31: 690-692.

33. Yoon HS (2009) Successful treatment of retroperitoneal infantile hemangioendothelioma with Kasabach-Merritt syndrome using steroid, alpha-interferon, and vincristine. J Pediatr Hematol Oncol 31: 952-954.

34. Mitsuhashi N (1997) Outcome of radiation therapy for patients with Kasabach-Merritt syndrome. Int J Radiat Oncol Biol Phys 39: 467-473. 
35. Blei F (1998) Successful multimodal therapy for kaposiform hemangioendothelioma complicated by Kasabach-Merritt phenomenon: case report and review of the literature. Pediatr Hematol Oncol 15: 295-305.

36. Argenta LC (1982) Complete resolution of life-threatening hemangioma by embolization and corticosteroids. Plast Reconstr Surg 70: 739-744.

37. Stanley P, Gomperts E, Woolley MM (1986) Kasabach-Merritt syndrome treated by therapeutic embolization with polyvinyl alcohol. Am J Pediatr Hematol Oncol 8: 308-311.

38. Phillips WG, Marsden JR (1993) Kasabach-Merritt syndrome exacerbated by platelet transfusion. J R Soc Med 86: 231-232.

39. Larsen EC (1987) Kasabach-Merritt syndrome: therapeutic considerations. Pediatrics 79: 971-980.

40. Watzke HH, Linkesch W, Hay U (1989) Giant hemangioma of the liver (Kasabach-Merritt syndrome): successful suppression of intravascular coagulation permitting surgical removal. J Clin Gastroenterol 11: 347-350.

41. Tlougan BE (2013) Medical management of tumors associated with Kasabach-Merritt phenomenon: an expert survey. J Pediatr Hematol Oncol 35: 618-622.

42. Janic D (200) The use of recombinant activated factor VII during major surgery in a child with Kasabach-Merritt syndrome. Paediatr Anaesth 19: 177-179.

43. Wang Z (2007) Kasabach-Merritt syndrome caused by giant hemangiomas of the spleen in patients with Proteus syndrome. Blood Coagul Fibrinolysis 18: 505-508.

44. Dresse MF (1991) Successful treatment of Kasabach-Merritt syndrome with prednisone and epsilon-aminocaproic acid. Pediatr Hematol Oncol 8: 329-334.

45. Hanna BD, Bernstein M (1989) Tranexamic acid in the treatment of Kasabach-Merritt syndrome in infants. Am J Pediatr Hematol Oncol 11: 191-195.

46. Ortel TL (1988) Antifibrinolytic therapy in the management of the Kasabach Merritt syndrome. Am J Hematol 29: 44-48.

47. Shulkin BL (1990) Kasabach-Merritt syndrome: treatment with epsilonaminocaproic acid and assessment by indium 111 platelet scintigraphy. J Pediatr 117: 746-749.

48. Yasui N (2013) Kasabach-Merritt phenomenon: a report of 11 cases from a single institution. J Pediatr Hematol Oncol 35: 554-558.

49. Wang P (2014) Clinical analysis of Kasabach-Merritt syndrome in 17 neonates. BMC Pediatr 14: 146.

50. Greenberger S (2010) Targeting NF-kappaB in infantile hemangiomaderived stem cells reduces VEGF-A expression. Angiogenesis 13: 327-335.

51. Giraldez A (2008) Kasabach-Merritt syndrome secondary to diffuse angiomatosis of the colon. Int J Colorectal Dis 23: 221-222.

52. Chen CE, Ko JY, Wang CJ (2002) Kasabach-Merritt syndrome complicating the treatment of a femoral shaft fracture in an adult. J Trauma 52: 789-792.

53. Ozsoylu S (1989) High-dose intravenous methylprednisolone for Kasabach-Merritt syndrome. Am J Hematol 31: 219-220.

54. Ozsoylu S (1993) Megadose methylprednisolone for Kasabach-Merritt syndrome. Pediatr Hematol Oncol 10: 197-198.

55. Ozsoylu S (1996) Megadose methylprednisolone therapy for KasabachMerritt syndrome. J Pediatr 129: 947-948.

56. Ozsoylu S (1996) Megadose methylprednisolone for Kasabach-Merritt syndrome. Eur J Pediatr 155: 149-150.

57. Ozsoylu S (2000) About the treatment of Kasabach-Merritt syndrome. Pediatr Hematol Oncol 17: 727-728.

58. Ozsoylu S (2003) Megadose methylprednisolone for Kasabach-Merritt syndrome. Eur J Pediatr 162: 562.

59. Ozsoylu S, Irken G, Gurgey A (1989) High dose intravenous methylprednisolone for Kassabach-Merritt syndrome. Eur J Pediatr 148 403-405.
60. Fernandez AP (2014) Kasabach-Merritt phenomenon in an adult man with a tufted angioma and cirrhosis responding to radiation, bevacizumab, and prednisone. Int J Dermatol 53: 1165-1176.

61. Fuchimoto Y (2012) Vincristine, actinomycin D, cyclophosphamide chemotherapy resolves Kasabach-Merritt syndrome resistant to conventional therapies. Pediatr Int 54: 285-287.

62. Haisley RC (2002) Kasabach-merritt phenomenon: a retrospective study of treatment with vincristine. J Pediatr Hematol Oncol 24: 459-462.

63. Barabash NR (2012) Kaposiform hemangioendothelioma with KasabachMerritt phenomenon: successful treatment with vincristine and ticlopidine. Indian J Pediatr 79: 1386-1387.

64. Fernandez PI (2013) Long-term outcome of vincristine-aspirinticlopidine (VAT) therapy for vascular tumors associated with KasabachMerritt phenomenon. Pediatr Blood Cancer 60: 1478-1481.

65. Wang Z (2015) Steroid-resistant kaposiform hemangioendothelioma: a retrospective study of 37 patients treated with vincristine and long-term follow-up. Pediatr Blood Cancer 62: 577-580.

66. Drolet BA (2013) Consensus-derived practice standards plan for complicated Kaposiform hemangioendothelioma. J Pediatr 163: 285-291.

67. Hurvitz SA (2000) Successful treatment with cyclophosphamide of lifethreatening diffuse hemangiomatosis involving the liver. J Pediatr Hematol Oncol 22: 527-532.

68. Read WL, Williams F (2016) Metastatic Angiosarcoma with KasabachMerritt Syndrome Responsive to Gemcitabine and Vinorelbine after Failure of Liposomal Doxorubicin and Paclitaxel: A Case Report. Case Rep Oncol 9: 177-181.

69. Alvarado Y (2011) Clinical activity of mammalian target of rapamycin inhibitors in solid tumors. Target Oncol 6: 69-94.

70. Hammill AM (2011) Sirolimus for the treatment of complicated vascular anomalies in children. Pediatr Blood Cancer 57: 1018-1024.

71. Blatt J (2010) Treatment of childhood kaposiform hemangioendothelioma with sirolimus. Pediatr Blood Cancer 55: 1396-1398.

72. Wang Z (2015) Successful treatment of Kasabach-Merritt phenomenon arising from Kaposiform hemangioendothelioma by sirolimus. J Pediatr Hematol Oncol 37: 72-73.

73. Jahnel J (2012) Kaposiform hemangioendothelioma with KasabachMerritt phenomenon: from vincristine to sirolimus. Klin Padiatr 224: 395-397.

74. Adams DM (2016) Efficacy and Safety of Sirolimus in the Treatment of Complicated Vascular Anomalies. Pediatrics 137: e20153257.

75. Ji Y (2017) Sirolimus for the treatment of progressive kaposiform hemangioendothelioma: A multicenter retrospective study. Int J Cancer 141: 848-855.

76. Schroeder U (2014) Laryngomalacia and complicated, life-threatening mTOR-positive Kaposiform hemangioendothelioma cured by Supraglottoplasty and sirolimus. Klin Padiatr 226: 362-368.

77. Kai L (2014) Sirolimus, a promising treatment for refractory Kaposiform hemangioendothelioma. J Cancer Res Clin Oncol 140: 471-476.

78. Osio A (2010) Clinical spectrum of tufted angiomas in childhood: a report of 13 cases and a review of the literature. Arch Dermatol 146: 758-763.

79. Leaute LC (1997) Tufted angioma associated with platelet trapping syndrome: response to aspirin. Arch Dermatol 133: 1077-1079.

80. Bornet G (2000) Cervicofacial angioma and the Kasabach-Merritt syndrome. Neuroradiology 42: 703-706.

81. Enjolras O (1997) Infants with Kasabach-Merritt syndrome do not have "true" hemangiomas. J Pediatr 130: 631-640.

82. O'Regan GM (2009) Mediastinal and neck kaposiform hemangioendothelioma: report of three cases. Pediatr Dermatol 26 : 331-337.

83. Enjolras O (1998) [Kasabach-Merritt syndrome on a congenital tufted angioma]. Ann Dermatol Venereol 125: 257-260.

84. Enjolras O (2000) Residual lesions after Kasabach-Merritt phenomenon in 41 patients. J Am Acad Dermatol 42: 225-235. 
85. Akyuz C (2003) Successful treatment with interferon alfa in infiltrating angiolipoma: a case presenting with Kasabach-Merritt syndrome. Arch Dis Child 88: 67-68

86. Biban P (2003) Kasabach-Merritt syndrome and interferon alpha: still a controversial issue. Arch Dis Child 88: 645-646.

87. Ezekowitz RA, Mulliken JB, Folkman J (1992) Interferon alfa-2a therapy for life-threatening hemangiomas of infancy. $\mathrm{N}$ Engl J Med 326: 1456-1463.

88. Smith AR (2008) Reversible skeletal changes after treatment with bevacizumab in a child with cutaneovisceral angiomatosis with thrombocytopenia syndrome. Pediatr Blood Cancer 51: 418-420.

89. Kline RM, Buck LM (2009) Bevacizumab treatment in multifocal lymphangioendotheliomatosis with thrombocytopenia. Pediatr Blood Cancer 52: 534-536.

90. Dupui GS (2012) Bevacizumab in patients with hereditary hemorrhagic telangiectasia and severe hepatic vascular malformations and high cardiac output. JAMA 307: 948-955.

91. Azma R (2014) Multifocal kaposiform hemangioendothelioma of soft tissue with bilateral pulmonary involvement in an adolescent. Korean J Pediatr 57: 500-504.

92. Chiu YE (2012) Variable response to propranolol treatment of kaposiform hemangioendothelioma, tufted angioma, and KasabachMerritt phenomenon. Pediatr Blood Cancer 59: 934-938.

93. Hermans DJ (2011) Kaposiform hemangioendothelioma with KasabachMerritt syndrome: a new indication for propranolol treatment. J Pediatr Hematol Oncol 33: e171-173.

94. Wang Z (2014) Variable response to propranolol treatment of kaposiform hemangioendothelioma, tufted angioma, and Kasabach-Merritt phenomenon. Pediatr Blood Cancer 61: 1518-1519.

95. Abass K (2008) Successful treatment of kasabach-merritt syndrome with vincristine and surgery: a case report and review of literature. Cases J 1: 9.

96. Drolet BA (2001) Early surgical intervention in a patient with KasabachMerritt phenomenon. J Pediatr 138: 756-768.

97. Jiang RS, Hu R (2012) Successful treatment of Kasabach-Merritt syndrome arising from kaposiform hemangioendothelioma by systemic corticosteroid therapy and surgery. Int J Clin Oncol 17: 512-516.

98. Dufau JP (1999) Isolated diffuse hemangiomatosis of the spleen with Kasabach-Merritt-like syndrome. Histopathology 35: 337-344.

99. Mahmoud NN (1999) Debulking of a gastrointestinal hemangioma alleviates coagulopathy associated with Kasabach-Merritt syndrome. Surgery 125: 236-238.

100. Tani A (2010) Extrahepatic portal venous obstruction due to a giant hepatic hemangioma associated with Kasabach-Merritt syndrome. J Nippon Med Sch 77: 269-272.

101. Gonzalez RFJ (2014) Urgent surgery in a Kasabach-Merrit syndrome associated with a giant hepatic angiosarcoma. Cir Esp 92: 370-372.

102. Malagari K (2007) Transarterial embolization of giant liver hemangiomas associated with Kasabach-Merritt syndrome: a case report. Acta Radiol 48: 608-612.

103. Garcia MR (2012) Kaposiform hemangioendothelioma with KasabachMerritt phenomenon: successful treatment with embolization and vincristine in two newborns. J Vasc Interv Radiol 23: 417-422.

104. Hosono S (1999) Successful transcutaneous arterial embolization of a giant hemangioma associated with high-output cardiac failure and Kasabach-Merritt syndrome in a neonate: a case report. J Perinat Med 27: 399-403.

105. Zhou SY (2013) Successful treatment of Kasabach-Merritt syndrome with transarterial embolization and corticosteroids. J Pediatr Surg 48: 673-676.

106. Komiyama M (2000) Endovascular treatment of huge cervicofacial hemangioma complicated by Kasabach-Merritt syndrome. Pediatr Neurosurg 33: 26-30.

107. Wolfe SQ (2009) Transarterial embolization of a scalp hemangioma presenting with Kasabach-Merritt syndrome. J Neurosurg Pediatr 4: 453-457.
108. Enomoto Y (2011) Transarterial embolization for cervical hemangioma associated with Kasabach-merritt syndrome. Neurol Med Chir 51: 375-378.

109. Lee JH, Roychowdhury S, Nissenblatt MJ (2014) Neuroembolization of metastatic Merkel cell cancer to the face for treatment of KasabachMerritt syndrome. J Neurointerv Surg 6: e3.

110. Shen W (2014) Treating kaposiform hemangioendothelioma with Kasabach-Merritt phenomenon by intralesional injection of absolute ethanol. J Craniofac Surg 25: 2188-2191.

111. Lee JJ (2012) Successful treatment of Kasabach-Merritt phenomenon with intralesional corticosteroid injections: a case series. Ann Plast Surg 69: 627-632.

112. Hochwald SN, Blumgart LH (2000) Giant hepatic hemangioma with Kasabach-Merritt syndrome: is the appropriate treatment enucleation or liver transplantation? HPB Surg 11: 413-419.

113. Biswal BM (1993) Vertebral haemangioma presenting as KasabachMerritt syndrome. Clin Oncol (R Coll Radiol) 5: 187-188.

114. Atahan IL (2001) Radiotherapy in the management of Kasabach-Merritt syndrome: a case report. Pediatr Hematol Oncol 18: 471-476.

115. Hesselmann S. (2002) Case report: Kasabach-Merritt syndrome: a review of the therapeutic options and a case report of successful treatment with radiotherapy and interferon alpha. Br J Radiol 75: 180-184.

116. Williams KM (2007) Radiotherapy for life-threatening mediastinal hemangioma with Kasabach-Merritt syndrome. Pediatr Blood Cancer 49: 739-744.

117. Leong E, Bydder S (2009) Use of radiotherapy to treat life-threatening Kasabach-Merritt syndrome. J Med Imaging Radiat Oncol 53: 87-91.

118. Malhotra Y (2014) Congenital kaposiform hemangioendothelioma with Kasabach-Merritt phenomenon successfully treated with low-dose radiation therapy. Pediatr Dermatol 31: 595-598.

119. Aylett SE (1990) The Kasabach-Merritt syndrome: treatment with intermittent pneumatic compression. Arch Dis Child 65: 790-791.

120. Velin P (1989) Neonatal Kasabach-Merritt syndrome healed by complete surgical excision of the angioma. Arch Pediatr 5: 295-297.

121. Alper A (1988) Treatment of liver hemangiomas by enucleation. Arch Surg 123: 660-661.

122. Aslan A (2009) Adult Kasabach-Merritt Syndrome due to Hepatic Giant Hemangioma. Case Rep Gastroenterol 3: 306-312.

123. Habringer S (2014) Kasabach-Merritt phenomenon in hepatic angiosarcoma. Br J Haematol 167: 716-718.

124. Imafuku S (2008) Kasabach-Merritt syndrome associated with angiosarcoma of the scalp successfully treated with chemoradiotherapy. Acta Derm Venereol 88: 193-194.

125. Bernathova M (2006) Primary angiosarcoma of the breast associated Kasabach-Merritt syndrome during pregnancy. Breast 15: 255-258.

126. Phillippe M, Acker D, Frigoletto FD (1980) Jr., Pregnancy complicated by the Kasabach-Merritt syndrome. Obstet Gynecol 56: 256-258.

127. Ontachi $Y$ (2005) Kasabach-Merritt syndrome associated with giant liver hemangioma: the effect of combined therapy with danaparoid sodium and tranexamic acid. Haematologica 90: Ecr29.

128. Mewes T (1989) The Kasabach-Merritt syndrome: severe bleeding disorder caused by celiac arteriography--reversal by heparin treatment. Am J Gastroenterol 84: 965-971.

129. Longeville JH (1997) Treatment of a giant haemangioma of the liver with Kasabach-Merritt syndrome by orthotopic liver transplant a case report. HPB Surg 10: 159-162.

130. Kumashiro Y (2002) Living donor liver transplantation for giant hepatic hemangioma with Kasabach-Merritt syndrome with a posterior segment graft. Liver Transpl 8: 721-724.

131. Warrell RP, Kempin SJ (1985) Treatment of severe coagulopathy in the Kasabach-Merritt syndrome with aminocaproic acid and cryoprecipitate. N Engl J Med 313: 309-312.

132. Menendez LR, Thommen VD (1995) Kasabach-Merritt syndrome complicating treatment of a closed femoral fracture. Clin Orthop Relat Res (316): 185-188. 
Citation: Master S, Kallam D, El-Osta H, Peddi P (2017) Clinical Review: Management of Adult Kasabach-Merritt Syndrome Associated with Hemangiomas . J Blood Disord Transfus 8: 397. doi:10.4172/2155-9864.1000397

Page 10 of 10

133. Shoji N (1998) Acute onset of coagulopathy in a patient with KasabachMerritt syndrome following transurethral resection of bladder tumor. Urol Int 61: 115-118.

134. Singh G, Rajendran C (1998) Kasabach-Merritt syndrome in two successive pregnancies. Int J Dermatol 37: 690-693.

135. Klompmaker IJ (1989) Orthotopic liver transplantation in a patient with a giant cavernous hemangioma of the liver and Kasabach-Merritt syndrome. Transplantation 48: 149-151.
136. Courcoutsakis NA (1997) Breast hemangiomas in a patient with Kasabach-Merritt syndrome: imaging findings. AJR Am J Roentgenol 169: 1397-1399.

137. Lee JH, Roychowdhury S, Nissenblatt MJ (2013) Neuroembolization of metastatic Merkel cell cancer to the face for treatment of KasabachMerritt syndrome. BMJ Case bcr2012010556-bcr2012010556. 